\title{
Peutz-Jeghers polyps, dysplasia, and K-ras codon 12 mutations
}

M M Entius, A M Westerman, F M Giardiello, M-L F van Velthuysen, $M$ M Polak, R J C Slebos, J H P Wilson, S R Hamilton, G J A Offerhaus

Department of Pathology, Academic Medical Centre, University of Amsterdam, The Netherlands M M Entius M M Polak R J C Slebos G J A Offerhaus

Department of Internal Medicine II, University Hospital Rotterdam, The Netherlands A M Westerman J H P Wilson

Department of Pathology, University Hospital Rotterdam, The Netherlands M-L F van Velthuysen

Department of Pathology and Oncology Centre, The Johns Hopkins University School of Medicine, Baltimore, USA

S R Hamilton

Department of Medicine, Division of Gastroenterology, The Johns Hopkins University School of Medicine, Baltimore, USA

F M Giardiello

Correspondence to: Professor Dr G J A Offerhaus, Department of Pathology, Academic Medical Centre, Meibergdreef 9, $1105 \mathrm{AZ}$ Amsterdam, The Netherlands.

Accepted for publication 20 December 1996

\begin{abstract}
Background-Peutz-Jeghers syndrome (PJS) is a rare, autosomal dominant, polyposis syndrome, associated with an increased risk of gastrointestinal and extragastrointestinal malignancy. Occasionally dysplasia occurs in PJS polyps.

Aims-In colorectal carcinomas, mutations in codon 12 of the K-ras oncogene are common and are found at similar frequency in precursor adenomas. Therefore, K-ras codon 12 point mutations in PJS polyps were evaluated.

Materials and methods-Fifty two PJS polyps, including four with dysplasia, collected from 19 patients with PJS, were analysed for mutations in the K-ras codon 12 by a mutant enriched polymerase chain reaction procedure, followed by allele specific oligodeoxynucleotide hybridisation. Results-A K-ras codon 12 mutation was identified in one colonic polyp with dysplasia. The mutation was found in the non-neoplastic epithelial cells and not in the dysplastic component of the polyp.

Conclusions-K-ras codon 12 point mutations are very rare in PJS polyps, by contrast with colorectal adenomas. The findings support previous evidence that there seems to be no intrinsic relation between K-ras codon 12 mutation and dysplasia.

(Gut 1997; 41: 320-322)
\end{abstract}

Keywords: Peutz-Jeghers syndrome; polyps; dysplasia; $\mathrm{K}$-ras codon 12 mutations

Peutz-Jeghers syndrome (PJS) is a rare autosomal dominant disorder defined by hamartomatous polyposis of the gastrointestinal tract and the occurrence of melanin spots on the lips and buccal mucosa. ${ }^{12}$ Polyps primarily occur in the small bowel, but are also found in the stomach and colon, and they range in size from a few millimeters to several centimeters. PJS polyps are classified as hamartomas because they are composed of epithelium consisting of the cellular elements normally present at that particular site of the gut and an excessive proliferation of smooth muscle extending into the lamina propria in an arborisation-like fashion. ${ }^{3}$ Patients with PJS can present with intussusception, anaemia, gastrointestinal bleeding, and intestinal obstruction. The germline mutation(s) responsible for PJS are as yet unknown, although linkage to chromosome $19 \mathrm{p}$ is reported. ${ }^{4}$
The hamartomatous polyps are not generally regarded as premalignant lesions. ${ }^{5}$ However, patients with PJS have a high relative risk of both intestinal and extraintestinal malignancies. ${ }^{6-10}$ Although no apparent direct relation exists between polyp formation and the risk of carcinoma formation, dysplasia is occasionally found in PJS polyps. By analogy to the adenoma-carcinoma sequence in colorectal cancer, ${ }^{11}$ carcinomas in the gastrointestinal tract may form due to progression of hamartoma to dysplasia to carcinoma. Molecular genetic alterations identifiable in hamartomatous PJS polyps might give an insight into the nature of the neoplastic risk. Tumorigenesis in the gastrointestinal tract results from an interaction between activation of dominantly acting oncogenes and inactivation of recessive tumour suppressor pathways. ${ }^{11}$ In the large bowel, the ras oncogene family is known to be invoved in the adenoma-carcinoma sequence. ${ }^{11}$ The ras oncogenes encode for closely related $21 \mathrm{kDa}$ proteins that function in cellular signal transduction, providing growth advantage. These proteins acquire transforming potential when altered at certain critical positions, in codons 12,13 , and $61 . .^{12}$ Activation of the ras oncogenes ( $\mathrm{H}$-ras, $\mathrm{K}$-ras and $\mathrm{N}$-ras) is seen in about $50 \%$ of colorectal cancers and their precursor adenomas. ${ }^{12}$ The most often encountered mutations are in codon 12 of K-ras and account for about $75 \%$ of ras mutations in tumours of the gastrointestinal tract. In this report we describe the analysis of 52 hamartomatous PJS polyps for K-ras mutations.

\section{Methods}

TISSUE SPECIMENS

Fifty two PJS polyps were collected from the pathology archives of the Academic Medical Centre of the University of Amsterdam, the University Hospital Rotterdam, and the Bowel Tumor Working Group Registry at The Johns Hopkins University School of Medicine. These were all hamartomatous polyps from the gastrointestinal tract (stomach $\mathrm{n}=4$, duodenum $n=14$, small intestine $n=18$, large bowel

TABLE 1 Histological characterisation of 52 polyps obtained from 19 patients with Peutz-Feghers syndrome

\begin{tabular}{lccc}
\hline & $\begin{array}{l}\text { Polyps without } \\
\text { dysplasia }\end{array}$ & $\begin{array}{l}\text { Polyps with } \\
\text { dysplasia }\end{array}$ & Total \\
\hline Stomach & 4 & 0 & 4 \\
Duodenum & 12 & 2 & 14 \\
Small bowel & 18 & 0 & 18 \\
Colorectum & 14 & $2^{\star}$ & 16 \\
Total & 48 & 4 & 52
\end{tabular}

^One polyp had a K-ras codon 12 mutation. 


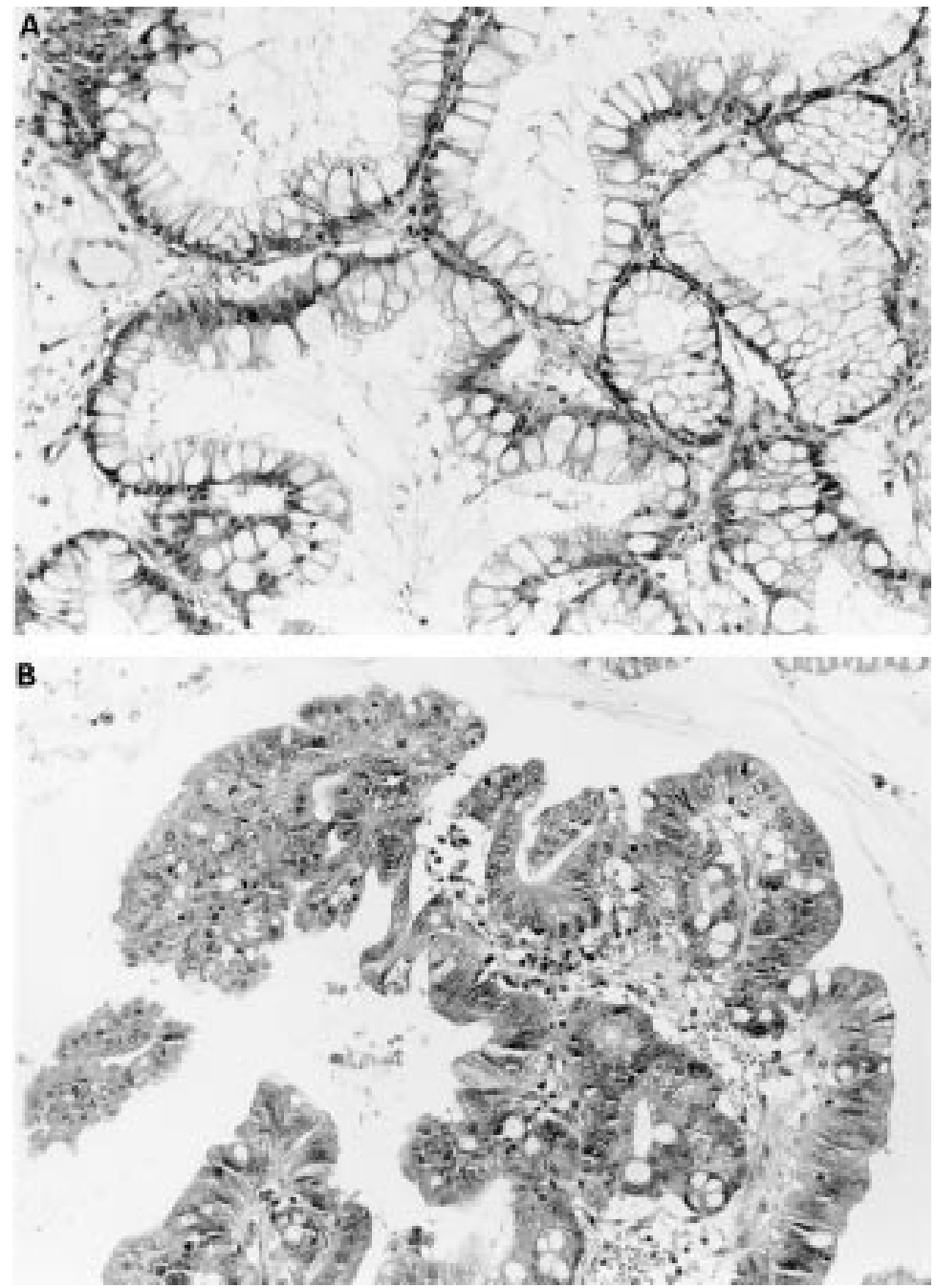

Figure 1: (A) Non-dysplastic and (B) dysplastic microscopic sections from the PFS polyp positive for a K-ras codon 12 mutation. This polyp shows heterogeneity for the K-ras mutation with the mutation solely found in the non-dysplastic section (haematoxylin and eosin).

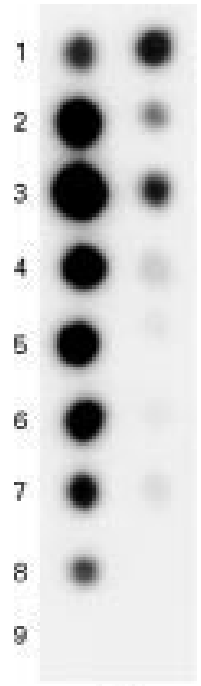

WT

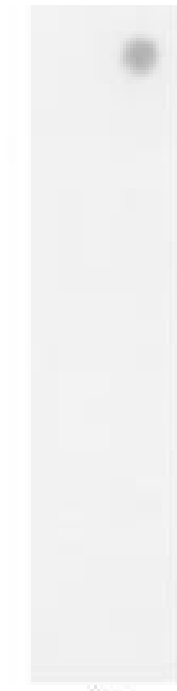

Arg

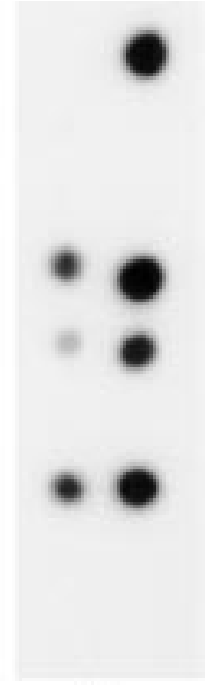

Val

Figure 2: Autoradiograph of K-ras codon 12 point mutation analysis in PYS polyps. Left column of the panels. mutant unenriched PCR products. Right column: mutant enriched PCR products. Row 1, positive control for wild type K-ras codon 12 (left column), positive controls for wild type K-ras codon 12, Arg mutant K-ras, and Val mutant K-ras (right column), respectively. Rows 2 and 3, PCR products from dysplastic section of the polyp with K-ras mutation (in duplicate). Rows 4 and 5, PCR products of non-dysplastic section (in duplicate). Row 6, PCR product of PYS polyp negative for K-ras codon 12 mutation. Row 7 , $P C R$ products from the entire PYS polyp positive for the K-ras mutation. Row 8, positive (placenta DNA) PCR control. Row 9, buffer only (negative) PCR control.

enzyme digestion using MvaI (an isoschizomer of BstNI; Boehringer Mannheim, Mannheim, Germany), reamplification of the digested and undigested polymerase chain reaction (PCR) products, and allele specific oligodeoxynucleotide hybridisation. For the first round of PCR sample DNA was amplified for 15 cycles $\left(94^{\circ} \mathrm{C}\right.$ 30 seconds; $62^{\circ} \mathrm{C} \quad 30$ seconds; $72^{\circ} \mathrm{C} \quad 60$ seconds) with primers A (5'-ACT GAA TAT AAA CTT GTG GTA GTT GGA CCT-3') and D (5'-TCA TGA AAA TGG TCA GAG AAA CC-3'). To enrich for the K-ras codon 12 mutants, the PCR products were then digested with MvaI to concentrate the mutant K-ras DNA fragments. Subsequently, a second round PCR was performed on both the digested and undigested first round PCR products. In the second round PCR, DNA was amplified for 35 cycles $\left(94^{\circ} \mathrm{C} 30\right.$ seconds; $55^{\circ} \mathrm{C} 30$ seconds; $72^{\circ} \mathrm{C} 60$ seconds) using primers $\mathrm{A}$ and $\mathrm{B}$ (5'-TCA AAG AAT GGT CCT GGA CC-3'). After denaturation the undigested and digested PCR products were spotted on to seven different nylon membranes (Genescreen Plus, NEN Research Products, Boston, MA, USA) and hybridised to each of the K-ras codon 12 specific oligodeoxynucleotides, as described previously. ${ }^{14}$ Positive controls comprised plasmid clones harbouring each of the possible sequence variations in codon 12 . Final stingency washes were carried out at $63^{\circ} \mathrm{C}$, followed by autoradiography. All analyses for $\mathrm{K}$-ras codon 12 mutations were performed in duplicate in two independently isolated DNA specimens. 


\section{Results}

A K-ras codon 12 mutation-with the wild type codon GGT (glycine) mutated to GTT (valine)-was identified in the DNA of one colonic polyp (figs 1 and 2). After separating the dysplastic epithelium from the remaining polyp tissue by microdissection, the mutation was solely found in the non-dysplastic area (fig 1), whereas the dysplastic epithelium lacked the mutation. No additional K-ras mutations were identified in the remaining 51 hamartomatous gastrointestinal polyps, of which three contained dysplasia (table 1). Also, in the 52 samples of the normal adjacent mucosa, no $\mathrm{K}$-ras codon 12 mutations were found.

\section{Discussion}

Hamartomatous PJS polyps have a neoplastic potential, ${ }^{15}$ but our study shows that activated $\mathrm{K}$-ras plays no obvious part in the process. In a previous cytogenetic study a normal karyotype was found in PJS polyps. ${ }^{16}$ To our knowledge, these are the first findings of a difference in genetic make up between hamartomatous PJS polyps and adenomatous polyps of the colorectum.

Of particular note, the DNA from the dysplastic epithelium of the PJS polyp with the mutation showed wild type K-ras at codon 12 and the mutation was found in the nondysplastic epithelium. Our finding raises questions about the role of ras mutations in colorectal carcinogenesis.

Aberrant crypt foci are microscopical lesions speculated to precede adenomatous polyp development. Ras mutations are often found in aberrant crypt foci in the mucosa of patients, but these lesions usually lack dysplasia. ${ }^{17-19} \mathrm{By}$ contrast, another event - for example, inactivation of the APC gene-seems to be needed to provide the dysplastic phenotype ${ }^{17}$ Apparently, ras activation provides a growth advantage but does not contribute to neoplastic transformation.

In summary, K-ras codon 12 mutations are very rare events in PJS polyps, by contrast with the high frequency of ras activation in adenomas and carcinomas of the large bowel. Furthermore, an intrinsic relation between K-ras codon 12 mutation and dysplasia was not noted. Further investigation is needed to elucidate the role and timing of $\mathrm{K}$-ras oncogene mutation in various forms of colorectal tumorigenesis.

1 Peutz JLA. Over een zeer merkwaardige, gecombineerde familiaire polyposis van de slijmvliezen van den tractus intestinalis met die van de neuskeelholte en gepaard met eigenaardige pigmentaties van de huid en slijmvliezen. Nederlandsch Maandschrift voor Geneeskunde 1921; 10: 134-6.

2 Jeghers H, McKusick VA, Katz KH. Generalized intestinal polyposis and melanin spots of the oral mucosa, lips and digits. N Engl f Med 1949; 241: 993-1031.

3 Haggitt RC, Reid BJ. Hereditary gastrointestinal polyposis syndromes. Am f Surg Pathol 1986; 10: 871-87.

4 Hemminki A, Tomlinson I, Markie D, Järvinen H, Sistonen P, Björkqvist A-M, et al. Localisation of a susceptibility locus for Peutz-Jeghers syndrome to $19 \mathrm{p}$ using comparative genomic hybridization and targeted linkage analysis. Nat Genet 1997 15: 87-90.

5 Spigelman AD, Murday V, Phillips RKS. Cancer and the Peutz-Jeghers syndrome. Gut 1989; 30: 1588-90.

6 Giardiello F, Welsh SB, Hamilton SR, Offerhaus GJA, Gittelsohn AM, Booker SV, et al. Increased risk of cancer in the Peutz-Jeghers syndrome. $N$ Engl f Med 1987; 316: 1511-4.

7 Utsunomiya J, Gocho H, Miyanaga T, Hamaguchi E, Kashimure A. Peutz-Jeghers syndrome: its natural course and management. Fohns Hopkins Medical fournal 1975; 136: $71-82$.

8 Perzin $\mathrm{KH}$, Bridge MF. Adenomatous and carcinomatous changes in hamartoma-tous polyps of the small intestine (Peutz-Jeghers syndrome): report of a case and review of the literature. Cancer 1982; 49: 971-83.

9 Settaf A, Mansori F, Bargash S, Saidi A. Peutz-Jeghers syndrome with carci-nomatous degeneration of a duodenal hamartomatous polyp. Ann Gastroenterol Hepatol 1990; 26: 285-8.

10 Hizawa K, Iida M, Matsumoto T, et al. Cancer in the Peutzeghers syndrome. Cancer 1993; 72: 2777-81.

11 Vogelstein B, Fearon ER, Hamilton SR, Kern SE, Preisinger AC, Leppert M, et al. Genetic alterations during colorectaltumor development. N Engl f Med 1988; 319: 525-32.

12 Bos JL. ras Oncogenes in human cancer: a review. Cancer Res 1989; 49: 4682-9.

13 Hruban RH, Van Mansfeld ADM, Offerhaus GJA, Van Weering DHJ, Allison DC, Goodman SN, et al. K-ras oncogene activation in adenocarcinoma of the human pancreas. A study of 82 carcinomas using a combination of mutant-enriched polymerase chain reaction analysis and allele-specific oligonucleotide hybridization. Am $\mathcal{F}$ Pathol 1993; 143: 545-54.

14 Slebos RJC, Boerrigter L, Evers SG, Wisman P, Mooi WJ, Rodenhuis $\mathrm{S}$. A rapid and simple procedure for detection of ras mutations in formalin-fixed paraffin-embedded tissue. Diagn Mol Pathol 1992; 1: 136-42.

15 Hizawa $\mathrm{K}$, Iida $\mathrm{M}$, Matsumto $\mathrm{T}$, Kohrogi $\mathrm{N}$, Yao $\mathrm{T}$, Fujishima $M$. Neoplastic transformation arising in PeutzJeghers polyposis. Dis Colon Rectum 1993; 36: 953-7.

16 Griffin CA, Lazar S, Hamilton SR, Giardiello FM, Long P, Krush A, et al. Cytogenetic analysis of intestinal polyps in polyposis syndromes: comparisons with sporadic colorectal adenomas. Canadian fournal of Genetic Cytology 1993; 67: adenomas

17 Jen J, Powell SM, Papadopoulos N, Smith KJ, Hamilton SR, Vogelstein B, Kinzler KW. Molecular determinants of dysplasia in colorectal lesions. Cancer Res 1994; 54: 5523-6.

18 Smith AJ, Stern HS, Penner M, Hay K, Mitri A, Bapat BV, Gallinger S. Somatic APC and K-ras codon 12 mutations in aberrant crypt foci from human colons. Cancer Res 1994; 54: $5527-30$

19 Chaubert P, Benhattar J, Saraga E, Costa J. K-ras mutations and p53 alterations in neoplastic and nonneoplastic lesions associated with longstanding ulcerative colitis. Am f Pathol 1994; 144: 767-75. 